\title{
Baimashania (Brassicaceae), a New Genus from China
}

\author{
Ihsan A. Al-Shehbaz \\ Missouri Botanical Garden, P.O. Box 299, St. Louis, Missouri 63166-0299, U.S.A.
}

Abstract. The new genus Baimashania and the new species $B$. pulvinata and $B$. wangii are described. The relationships and characters distinguishing Baimashania from Solmslaubachia, Leiospora, and Pycnoplinthus are discussed.

During a recent revision of Solmslaubachia Muschler for the forthcoming account of the Brassicaceae for the Flora of China, Al-Shehbaz and Yang (2000) excluded three collections previously misidentified as S. ciliaris (Bureau \& Franchet) Botschantsev from the genus for subsequent studies. These three collections are placed herein in the new genus Baimashania. Except for the smaller flower size, the type specimen of $S$. ciliaris is indistinguishable in all other morphological aspects from that of the earlier published $S$. pulcherrima Muschler, a species highly variable in petal length and color. In fact, the type of $S$. ciliaris has petals ca. $1.5 \mathrm{~cm}$ long, while $S$. pulcherrima has petals (1.5-)1.7-2(-2.5) cm long. Therefore, the two are considered to be conspecific.

The recognition of Solmslaubachia ciliaris in various works (e.g., Lan \& Cheo, 1981; Kuan, 1985; Lan, 1987; Wang, 1993; Ying et al., 1993; Li et al., 1995; Huang, 1997; Tan et al., 1999) basically followed Botschantsev (1955), who did not examine the type material of the species and erroneously interpreted its limits. In fact, illustrations and descriptions of $S$. ciliaris in these works are based on species of different genera. For example, the accounts in Kuan (1985), Wang (1993), and Ying et al. (1993) were based on one collection, QinghaiXizang Team 73-399 (KUN, PE), which is a misidentified young plant of Leiospora pamirica (Botschantsev \& Vvedensky) Botschantsev \& Pachomova. By contrast, the descriptions and illustrations in Lan and Cheo (1981), Lan (1987), Li et al. (1995), and Tan et al. (1999) are based on a new species in a new genus herein described as Baimashania pulvinata, whereas the account in Huang (1997) is based on the new species B. wangii.

Baimashania is named after Baima Shan (sometimes spelled Beima Shan, Beimashan, or Paimashan), a mountain in northwestern Yunnan from which four of the five known collections of the genus are known. It differs from all nine species of
Solmslaubachia (China, Sikkim) and six species of Leiospora (C. A. Meyer) Dvořák (China, Himalayas, and central Asia) in having median nectar glands confluent with the laterals, distinct and slender styles, flowers only to $4 \mathrm{~mm}$ long, fruit septa with a distinct midvein, obscurely veined, flat-margined fruit valves that are readily detached from replum at the fruit apex, replums readily distinguished from the valve margins, and narrow fruits (1-1.3 $\mathrm{mm}$ wide) persistent on the pedicel apex. By contrast, Solmslaubachia and Leiospora lack the median nectar glands and styles, and have much larger flowers 10-26 mm long, veinless fruit septa, prominently veined, marginally strongly angled fruit valves apically adnate to the replum, replums concealed by the valve margins, and broad fruits, (3-)5-15(-20) $\mathrm{mm}$ wide, readily detached from the pedicel apex. Furthermore, Baimashania also differs from Solmslaubachia by having forked trichomes mixed with simple ones and minutely reticulate seeds, while Solmslaubachia is glabrous or has only simple trichomes and has papillate, rugose, or coarsely reticulate seeds. It also differs from Leiospora by having entire stigmas, 6- to 12 ovuled ovaries, nonsaccate lateral sepals, and wingless seeds. Leiospora has prominently 2 -lobed stigmas, 18- to 50-ovuled ovaries, saccate lateral sepals, and often winged seeds.

The first collection of Baimashania, Forrest 19605 (see below), in July 1921 was misidentified by Edgar Evans as "Braya sp. aff. forrestii W. W. Smith." Baimashania pulvinata differs from Braya forrestii in having flattened, linear fruits, accumbent cotyledons, forked and simple trichomes, a confluent nectar ring, and much smaller, solitary flowers. By contrast, Braya forrestii has terete, ovoid fruits, incumbent cotyledons, exclusively simple trichomes, four separate nectar glands, and larger flowers in distinct racemes. In my opinion, Baimashania and Braya Sternberg \& Hoppe are not related.

Perhaps Baimashania is most similar to Pycnoplinthus O. E. Schulz (one species; China, India, Kashmir, Pakistan), with which it shares the perennial, pulvinate, scapose habit, solitary pink flowers, persistent entire leaves, thickened petioles, obtuse

Novon 10: 320-322. 2000. 
anthers, 6- to 12-ovuled ovaries, linear flattened fruits, entire stigmas, and uniseriate wingless seeds. However, it differs by having branched trichomes, free sepals, distinct median glands confluent with the laterals, obscurely veined valves, and accumbent cotyledons. Pycnoplinthus consists of glabrous plants with united sepals, no median nectar glands, prominently veined valves, and incumbent cotyledons.

Baimashania Al-Shehbaz, gen. nov. TYPE: Baimashania pulvinata Al-Shehbaz.

Herba perennis scaposa pulvinata, caudice ramoso. Folia basalia rosulata, integra, persistentia, pilis simplicibus et furcatis, petiolis crassis complanatis, ciliatis. Racemi 2- vel 3-flori vel flores solitarii. Sepala oblonga nonsaccata. Petala rosea, spathulata, obtusa. Glandulae nectariferae confluentes. Ovula 6-12. Fructus lineares valde compressi glabri; valvis longitudinaliter striatis nontorulosis; stylo tenui ad $1 \mathrm{~mm}$ longo; stigmata integra. Semina uniseriata, oblonga; cotyledones accumbentes.

Herbs perennial, scapose, pulvinate, with a welldeveloped, few- to many-branched caudex covered by leaves or leaf remains of previous years. Trichomes simple mixed with stalked, 1-forked ones, restricted to leaves. Stems absent. Basal leaves petiolate, rosulate, simple, entire, persistent, with stramineous, thick, basally flattened, ciliate petioles. Cauline leaves absent. Racemes 2- or 3-flowered and ebracteate, or flowers solitary on short pedicels originating from axils of rosette leaves. Fruiting pedicels slender, erect to ascending, often hidden among basal leaves. Sepals oblong, deciduous, erect, equal, base of inner pair not saccate, margin membranous. Petals pink; blade spatulate, apex obtuse; claw slightly differentiated from blade, subequaling sepals. Stamens 6 , slightly tetradynamous; filaments not dilated at base; anthers oblong, not apiculate at apex. Nectar glands confluent and subtending bases of all stamens; median nectaries present. Ovules 6 to 12 per ovary. Fruit dehiscent, capsular siliques, linear, strongly latiseptate, sessile; valves with an obscure midvein, glabrous, not torulose, longitudinally striate; replum rounded, visible; septum complete, membranous, with a distinct midvein; style slender, to $1 \mathrm{~mm}$ long; stigma capitate, entire. Seeds uniseriate, wingless, oblong; seed coat minutely reticulate, not mucilaginous when wetted; cotyledons accumbent.

Two species: endemic to China (Yunnan and Qinghai provinces).

\section{Key to THE Species of BaIMASHANIA}

la. Leaves ovate to oblong, densely pilose throughout; flowers solitary; ovules 6 to 8 per ovary; Yunnan 1. B. pulvinato 1b. Leaves linear, glabrous except for ciliate petiole margins and a tuft at leaf apex; flowers mostly in 2 - or 3 -flowered racemes; ovules 10 to 12 per ovary; Qinghai

2. B. wangii

1. Baimashania pulvinata $\mathrm{Al}-\mathrm{Shehbaz}$, sp. nov. TYPE: China. Yunnan: Deqen, Baima Shan, N side of road, limestone rock crevices, $28^{\circ} 23^{\prime} \mathrm{N}$, $99^{\circ} 01^{\prime} \mathrm{E}, 4350 \mathrm{~m}$, 30 June 1994, Alpine Garden Society Expedition to China ACE 829 (holotype, $\mathrm{K}$; isotype, $\mathrm{MO}$ ).

Herba pulvinata $0.5-2 \mathrm{~cm}$ alta, caudice multiramoso. Folia basalia ovata vel oblonga, $2-4 \times 1-2 \mathrm{~mm}$, subcarnosa, omnino dense pilosa. Flores solitarii. Pedicelli fructiferi 3-5 mm longi. Sepala oblonga $1.5-2.5 \times$ ca. $1 \mathrm{~mm}$. Petala rosea, $3-4 \times 1-1.5 \mathrm{~mm}$; ungues $1.5-2 \mathrm{~mm}$ longi. Ovula 6-8. Fructus lineares, $4-8 \times 1-1.3 \mathrm{~mm}$; stylo 0.4 $1 \mathrm{~mm}$ longo. Semina $1-1.5 \times 0.6-0.9 \mathrm{~mm}$.

Herbs pulvinate, $0.5-2 \mathrm{~cm}$ tall; caudex many branched, to $3 \mathrm{~mm}$ diam. Trichomes simple, to 1 mm long, mixed with fewer forked stalked ones, restricted to leaves. Basal leaves rosulate; petiole 2-5 mm long, expanded at base and 0.5-1 mm wide, ciliate, persistent; leaf blade ovate to oblong, $2-4 \times 1-2 \mathrm{~mm}$, somewhat fleshy, densely pilose throughout, base subattenuate, margin entire, apex obtuse. Flowers solitary. Fruiting pedicel slender, 3-5 mm long, ascending, glabrous. Sepals oblong, 1.5-2.5 $\times$ ca. $1 \mathrm{~mm}$. Petals pink, spatulate, $3-4 \times$ 1-1.5 mm; claw 1.5-2 mm long. Filaments 2-2.5 $\mathrm{mm}$ long; anthers $0.3-0.5 \mathrm{~mm}$ long. Ovules 6 to 8 per ovary. Fruit linear, $4-8 \times 1-1.3 \mathrm{~mm}$; valves longitudinally striate, without a distinct midvein; style $0.4-1 \mathrm{~mm}$ long. Seeds $1-1.5 \times 0.6-0.9 \mathrm{~mm}$. Flowering June-July, fruiting July-August.

Habitat. Moist gravelly meadows, limestone rock crevices; 4200-4600 m. Yunnan.

Baimashania pulvinata was illustrated in Lan (1987) as Solmslaubachia ciliaris. The illustration accurately shows the habit of the plant, leaf shape and trichomes, and mature fruit, and, therefore, should be consulted for reference. The holotype was misidentified as Braya of. forrestii, though nothing was mentioned about it in the detailed account of the expedition that led to its discovery (Grey-Wilson, 1996).

Paratypes. CHINA. Yunnan: Baima Shan, $28^{\circ} 18^{\prime} \mathrm{N}$, $99^{\circ} 10^{\prime} \mathrm{E}$, G. Forrest 19605 (E, K, US); Atuntze, Baima Shan, Shulung, T. T. Yӥ 9324 (KUN, PE); Deqen, Baima Shan, Qing-Zang Team 2779 (KUN); Deqin Xian, Baima Shan, mts. $\mathrm{N}$ of $\mathrm{W}$ pass, $28^{\circ} 23^{\prime} \mathrm{N}, 9^{\circ} 01^{\prime} \mathrm{E}$, Aldén, Alexander, Long, McBeath, Noltie \& Watson 765 (E). 
2. Baimashania wangii Al-Shehbaz, sp. nov. TYPE: China. Qinghai: Nangqen Xian, Xiaoqu, $\mathrm{S}$ bend, under rocks, 13 June 1982, 4100 m, Wang Weiyi 0011 (holotype, HNWP; fragment, MO).

Herba pulvinata $1-1.5 \mathrm{~cm}$ alta, caudice pauciramoso, Folia linearia, 4-15 $\times 0.5-1.5 \mathrm{~mm}$, subcarnosa, praeter apicem pilosam glabra, petiolibus ciliatis. Racemi fructiferi 2- vel 3-fructi vel fructus solitarii. Pedicelli fructiferi $3-5 \mathrm{~mm}$ longi. Flores ignoti. Ovula 10-12. Fructus lineares, $0.7-1.3 \mathrm{~cm} \times$ ca. $1 \mathrm{~mm}$; stylo $0.4-0.7 \mathrm{~mm}$ longo. Semina ignota.

Herbs pulvinate, 1-1.5 cm tall; caudex few branched, to $6 \mathrm{~mm}$ diam. Trichomes simple, to 1 $\mathrm{mm}$ long, restricted to petiole margins and leaf apices, these mixed at leaf apex with fewer forked stalked ones. Basal leaves rosulate; petiole $2-5 \mathrm{~mm}$ long, expanded at base and $0.5-1.5 \mathrm{~mm}$ wide, ciliate; leaf blade linear, 4-15 × 0.5-1.5 mm, somewhat fleshy, base attenuate, margin entire, apex with a tuft of hairs, obtuse. Fruiting racemes with 2 or 3 fruits, sometimes fruits solitary. Fruiting pedicel slender, 3-5 mm long, ascending, glabrous. Flowers not seen. Ovules 10 to 12 per ovary. Fruit linear, $0.7-1.3 \mathrm{~cm} \times$ ca. $1 \mathrm{~mm}$; valves not torulose; style $0.4-0.7 \mathrm{~mm}$ long. Mature seeds not seen. Fruiting June.

Baimashania wangii, which is named after the collector of the holotype, is known thus far only from the type collection. The type was annotated in 1995 by Huang Rong-fu as Solmslaubachia ciliaris, and it is very likely that the record of $S$. ciliaris from Qinghai (Huang, 1997) was erroneously based on the holotype of $B$. wangii.
Acknowledgments. I am indebted to Henk van der Werff for correcting the Latin. I thank Sue Zmarzty for her permission to deposit at MO an isotype of Baimashania pulvinata. I also thank the directors and curators of the herbaria cited, as well as Zhu Guanghua, $\mathrm{He} \mathrm{Si}$, and Song Hong for their help in the translation of labels from Chinese.

\section{Literature Cited}

Al-Shehbaz, I. A. \& G. Yang. 2000. A revision of Solmslaubachia (Brassicaceae). Harvard Pap. Bot. (in press).

Botschantsev, V. 1955. De Cruciferis notae criticae. Bot. Mater. Gerb. Bot. Inst. Komarova Akad. Nauk S.S.S.R. 17: $160-178$.

Grey-Wilson, C. 1996. The Alpine Garden Society Expedition to China. Quart. Bull. Alpine Gard. Soc. 64: 122164.

Huang, R. F. 1997. Cruciferae. In: S. W. Liu (editor), Fl. Qinghai. 1: 410-505. Qinghai People's Publishing House, Xining.

Kuan, K. C. 1985. Solmslaubachia. In: C. Y. Wu (editor), Fl. Xizang. 2: 381-384. Science Press, Beijing.

Lan, Y. Z. 1987. Solmslaubachia. In: T. Y. Cheo (editor), Fl. Reipubl. Popularis Sin. 33: 326-339. Science Press, Beijing.

— \& T. Y. Cheo. 1981. On the Chinese genus Solmslaubachia Muschler (Cruciferae). Acta Phytotax. Sin. 19: 472-480.

Li, X. W. et al. 1995. Cruciferae. In: C. Y. Wu, C. Chen \& S. K. Chen (editors), Fl. Yunnan. 6: 1-121. Science Press, Beijing.

Tan, Z. M., Z. Q. Zhang, Y. Zhao \& S. D. Zhou. 1999. Cruciferae. In: Z. M. Tan (editor), Fl. Sichuan. 14: 1181. Sichuan Nationality Press, Chengdu.

Wang, W. T. 1993. Cruciferae. In: W. T. Wang et al. (editors), Vascular Plants of the Hengduan Mountains. 1: 618-652. Science Press, Beijing.

Ying, T. S., Y. L. Zhang \& D. E. Boufford. 1993. The Endemic Genera of Seed Plants of China. Science Press, Beijing. 


\section{$2 \mathrm{BHL}$ Biodiversity Heritage Library}

Al-Shehbaz, Ihsan A. 2000. "Baimashania (Brassicaceae), a new genus from China." Novon a journal of botanical nomenclature from the Missouri Botanical Garden 10, 320-322.

View This Item Online: https://www.biodiversitylibrary.org/item/14670

Permalink: https://www.biodiversitylibrary.org/partpdf/38234

\section{Holding Institution}

Missouri Botanical Garden, Peter H. Raven Library

\section{Sponsored by}

Missouri Botanical Garden

\section{Copyright \& Reuse}

Copyright Status: In copyright. Digitized with the permission of the rights holder.

License: http://creativecommons.org/licenses/by-nc-sa/3.0/

Rights: https://biodiversitylibrary.org/permissions

This document was created from content at the Biodiversity Heritage Library, the world's largest open access digital library for biodiversity literature and archives. Visit BHL at https://www.biodiversitylibrary.org. 